\title{
4. A Robinson Crusoe in Arnhem Land: Howell Walker, National Geographic and the Arnhem Land Expedition of 1948
}

\author{
Mark Collins Jenkins
}

\begin{abstract}
'A tall, dark, handsome stranger has come into my life-and gone', a California newspaperman once jocularly wrote in the early 1950s. 'Now what nationality would you say that man was?' he reported a friend of his asking. ${ }^{1}$
\end{abstract}

That cultured accent, that refined deportment, and those Cary Grant good looks that suggested a citizen of the world belonged to a correspondent named Harrison Howell Walker, who happened to be travelling in California on a National Geographic magazine assignment. Yet the newspaperman's reaction was scarcely unique, for Walker left the same impression on nearly everyone he met. In December 1953, for instance, he and a Geographic colleague were covering the royal visit of Queen Elizabeth II to Fiji and Tonga. In Fiji, the members of the press were all shacked up in one large tent. One morning, Eliot Elisofon of Life magazine awoke, pushed back his mosquito netting, looked around him, and declared, 'Well, here we are, all 21 of us - 19 journalists and two gentlemen from the Geographic.'2

He might have been the National Geographic's 'parfit gentil Knight', as one Chaucerian-minded colleague dubbed him, but when Howell Walker strolled back into the camp of the American-Australian Scientific Expedition to Arnhem Land after having been 'lost' for days in the Northern Territory's stormy Gulf of Carpentaria, he became its 'intrepidest' explorer as well. Both gentleman and adventurer, he was the epitome of the Geographic's foreign editorial staffthose dexterous individuals who, as representatives of a non-partisan scientific and educational organisation, were in journalism but not of it. Unaided, each could write articles, take still pictures, and make a $16 \mathrm{~mm}$ motion picture while wandering about the world, though always following the high road.

\footnotetext{
1 Clippings: ‘Walker, Howell', Library News Collection, National Geographic Society Library, Washington, DC.

2 Hunter, C. 2003, 'Howell Walker', National Geographic TimeLine Biography, National Geographic Archives, Washington, DC.
} 
No examination of the legacies of the 1948 Arnhem Land Expedition would be complete without a glance at the role played by the National Geographic and its intrepid representative. Founded in 1888 to 'increase and diffuse geographic knowledge', the National Geographic Society had by the 1940s become a dignified, almost hallowed, and thoroughly American institution, its famous oak-and-laurel trimmed magazine sent each month to more than one million members - 90 per cent of whom lived in the United States. Behind the Arnhem Land Expedition one might glimpse how it was that the National Geographic Society of that era went about its business, how it construed its mission as both a sponsor of science and a populariser of 'humanised geography', and how central was the role of photography in its activities. Howell Walker, the society's roving writer-photographer, strayed through Arnhem Land constrained on the one hand by the demands of popular Kodachrome travelogues, whether printed or projected, and on the other by America's hunger for images of the faraway and exotic. 'In an unruffled and Princetonian way', the California newspaperman continued, 'Walker investigated and reported on far-off, rugged places, in the National Geographic manner'.

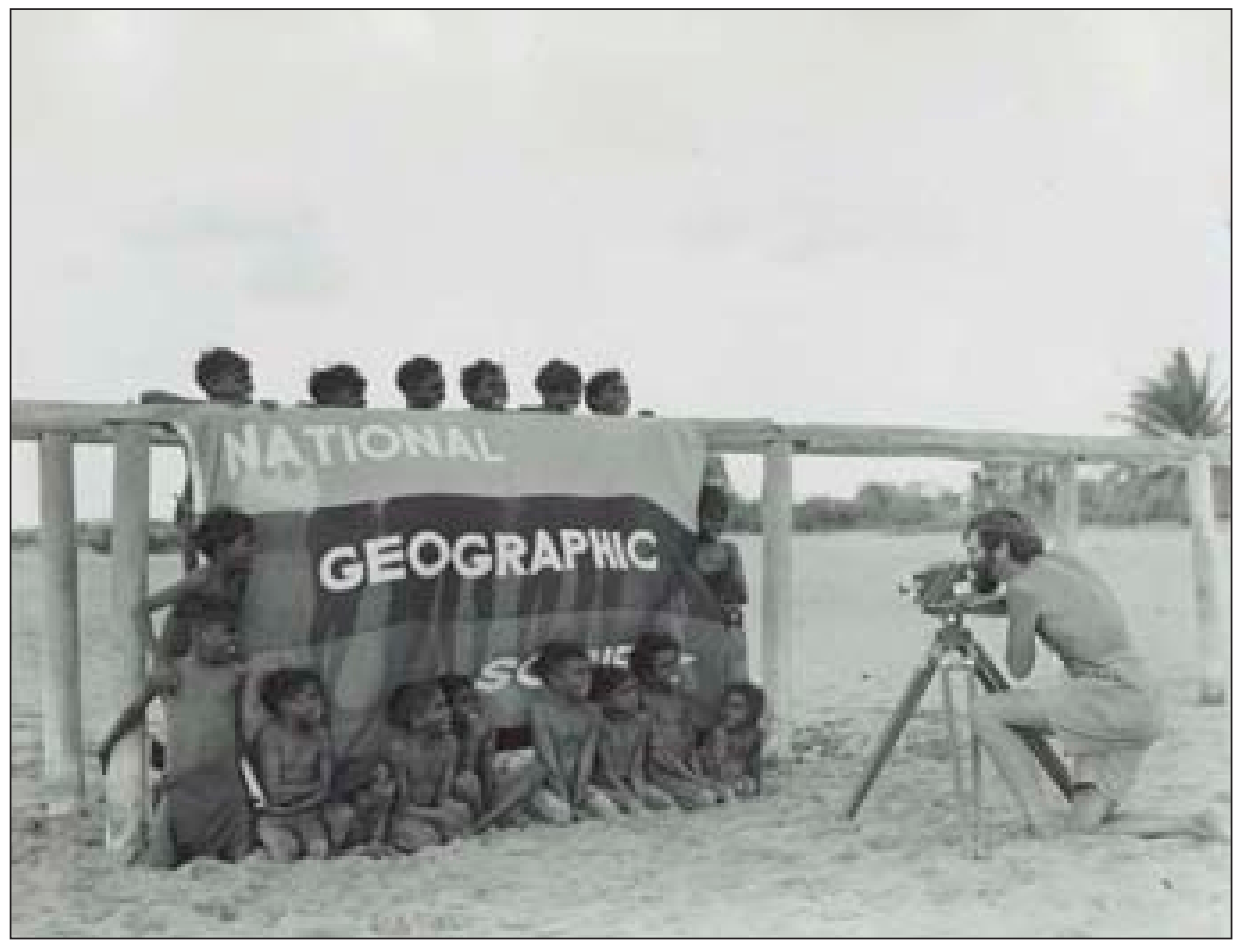

Figure 4.1 Howell Walker from the National Geographic Society photographing at Umbakumba, 1948

Photograph by Charles P. Mountford. By permission of the State Library of South Australia. PRG487/1/2/209/1. 


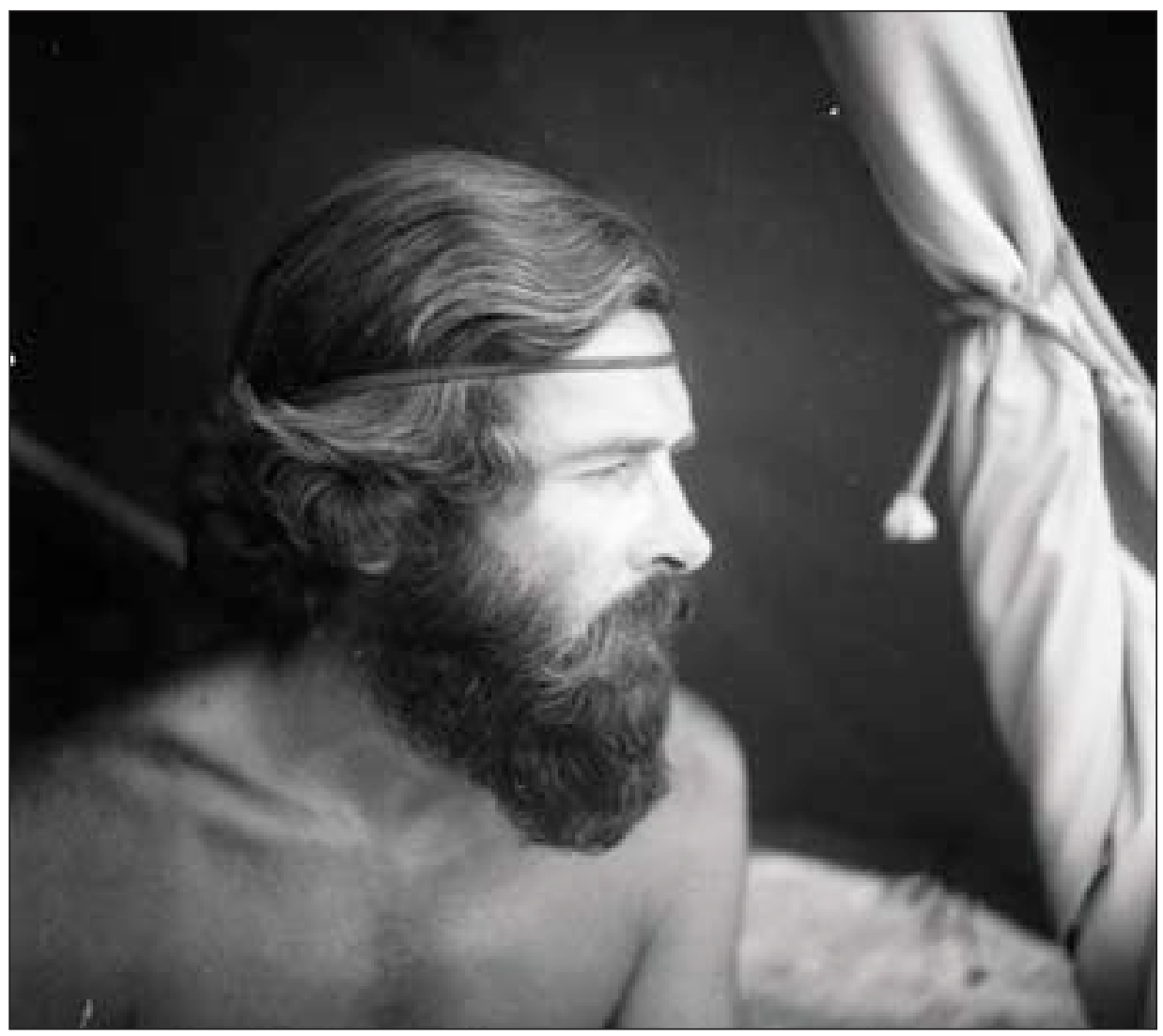

Figure 4.2 Howell Walker during the Arnhem Land Expedition, 1948

Photograph by Charles P. Mountford. By permission of the State Library of South Australia. PRG1218/34/2859.

$$
\text { * }
$$

That manner was made not born. What was born that drizzly winter night in January 1888 in the old Cosmos Club one block from the White House was but another scientific and professional association to be caught up in the social whirl of late nineteenth-century Washington, DC. It was tentatively called the 'Society of Geography', and its founders voted to call themselves the National Geographic Society because, first, an American Geographical Society had already existed in New York since 1851, and second, it aspired to be not merely a local, Washington-based society, but to attract members from all over the United States. 
Yet it was undeniably local and thoroughly professional. The majority of its 33 founders were government scientists working for such great and growing Washington-based bureaus as the US Geological Survey and the US Coast and Geodetic Survey; tellingly, only one was a journalist. But Washington for the most part was only their winter home. These geologists and mapmakers spent their summers in the field, dispersed all over the continent, converging back upon the capital each autumn to write their reports, dispose of their collections, and of course socialise with one another through the city's numerous clubs and organisations. They might have worked for competing and sometimes mutually hostile agencies, but they were, in their own way, companions in geography, for that was the metier they shared.

If not yet a national institution, the society quickly became a Washington one. It was no Smithsonian, of course; rather it resembled a local history society or garden club. It had no such thing as paid staff or a permanent headquarters. Its officers were elected by the membership at large and worked on society matters in their free time. The organisation was social as well as professional; it held popular annual field trips to such nearby points of geographical interest as Civil War battlefields. It threw grand parties and receptions honouring visiting explorers and dignitaries. It mounted a lecture program, held in various venues in the city each winter, although the 'excessive use of picture and anecdote', as one society officer in the 1890s declaimed, 'is discouraged'. ${ }^{3}$ Such bleakly austere addresses were then printed in a slim, brown-backed journal of proceedings, issued sometimes quarterly, sometimes irregularly, and finally monthly, called the National Geographic magazine. Often on such laudable topics as orogeny, physiography or hydrology, these articles were sometimes so impenetrably dense that they were read only by experts - 'diffusing geographic knowledge', as one wag put it, 'among those who already had it and scaring off the rest'.

The upshot was that after its first president and chief patron, Gardiner Greene Hubbard, died in December 1897, the fledgling National Geographic Society found itself teetering on the brink of bankruptcy. The board, casting around for his replacement, persuaded Hubbard's son-in-law, who did not want the job, to take it anyway. His name was Alexander Graham Bell.

In the five years (1898-1903) that the famous inventor of the telephone was President of the National Geographic Society, he planted the seeds of a new conception of it - one that ultimately steered it in a direction perhaps radically different from its founders' original vision. Though he virtually abandoned the

3 Bryan, C. D. B. 1987, The National Geographic Society: 100 years of adventure and discovery, Harry N. Abrams, New York, p. 33.

4 Ibid, p. 28. 
society during his first year in the post, the corpulent, insatiably curious Bell eventually girded up his substantial loins and applied himself to the task of making the society successful.

In order to make the National Geographic Society truly national, he concluded, he had to expand its base of membership. According to Bell-who was no geographer - in order to swell its membership ranks, the society would have to reach beyond its narrow circle of professional geographers and invite ordinary people to enlist on its rolls. The way to do that was precisely through the excessive use of picture and anecdote. And the vehicle for that should be the National Geographic magazine, made so bright and engaging and inviting that many people should find it irresistible; however-and this was a key part of the strategy - it could be obtained only through membership in the National Geographic Society, of which it was the official journal. But unlike the Smithsonian Institution, for instance, which grew out of a substantial bequest to 'increase and diffuse knowledge' and which first operated as a research institution, then as a series of museums (and only in the mid-twentieth century invited a popular membership through its magazine), the National Geographic Society was born without a cent to its name.

What happened next is part of magazine publishing legend. In 1899, Bell hired the society's first full-time employee - paid out of his own pocket - to help put his ideas into action. Twenty-three-year-old Gilbert Hovey Grosvenor had been courting Bell's daughter. He would also prove to be an editor of genius. Spurred by Bell's ideas, he swiftly transformed the society's dowdy journal into a magazine of wide appeal by publishing as many photographs of exotic corners of the globe as he could lay his hands on. His pictorial eye had been sharpened early in life, for he had been born and reared in Constantinople. In the last quarter of the nineteenth century, the capital of the Ottoman Empire was a crossroad for every picturesque tribe in the Near East - at least as they surely appeared to stiff dyed-in-the-wool New Englanders such as the Grosvenors. Moreover, Grosvenor adopted colour photography at an early stage in its development, when it was still a demanding technique mastered only by a few practitioners. It was extremely expensive to engrave and print in magazines, and even then the results were hardly convincing. Nevertheless, Grosvenor stuck with it. Through colour, he would open a window on the world for his members, and colour photography soon became the signature of National Geographic.

He was successful almost certainly beyond his wildest dreams. If Bell was the architect of today's National Geographic Society, as has been said, Grosvenor was its master builder. He laboured away at it for more than half a century (from 1899 until 1954), watching the membership grow from something less than 1000 
when he first arrived, to half a million by 1916, and to more than one million by the 1920s - the 'first million', as a tagline in the magazine used to put it, for Grosvenor was not only a born editor but a born promoter, too.

Geography at the society thus became geography broadly construed - 'the world and all that is in it', in Bell's famous phrase. That meant plants and animals joined the long parade of quaintly costumed humanity, marching, creeping, swimming or flying through the magazine's pages. Though it changed the character of the institution forever - gone were the articles on orogeny or hydrology; while such relentless popularisation drove off many of the academic or professionally oriented original members - it did allow, ironically, a fuller realisation of the stated mission to 'increase and diffuse' geographic knowledge. That seemed conventional enough. The Smithsonian, after all, was founded for the 'increase and diffusion of knowledge' and the Carnegie Institution of Washington for the 'increase and diffusion of knowledge among men'. Yet by swelling the ranks of the National Geographic Society with middle-class members who dreamed of faraway places and pored over the magazine's pictures of the exotic 'Other', Grosvenor was able to fill the organisation's coffers to overflowing in a remarkably short time. This allowed it to start sponsoring expeditions of exploration and discovery.

Although the society had been lending its name to such field expeditions since 1890, that was about all it lent; it had not a dollar to spare. By 1906, however, it had amassed enough funds to put its money where only its seal had previously been. Its first such expedition was Robert E. Peary's to the North Pole. Soon the society was supporting expeditions large and small to the far corners of the New World - from Alaska's Valley of Ten Thousand Smokes to the fabulous ruins of Machu Picchu in Peru. Often it teamed up with the Smithsonian Institutionexcavating the ruins of Chaco Canyon in New Mexico during the 1920s and virtually uncovering the vanished Olmec civilisation in tropical Mexico during the 1930s and 1940s. A pattern arose out of such partnerships: the Smithsonian, say, or the American Museum of Natural History in New York, or Yale University would get the physical collections, while the National Geographic would get the pictures and first publication rights. The engine that drove the society- the two-piston beat of increase and diffusion - was finally operating at maximum efficiency. Not only was the incredible success of National Geographic's middlebrow presentation of the world funding its scientific expeditions, those expeditions were chosen by the society's Research Committee with one eye on their appeal to their far-flung membership. An appealing expedition would then provide ample fodder for the magazine, thus closing the feedback loop.

Grosvenor might have been a master builder, but he had Edwardian notions of propriety. Though many of the contributors on whom he depended might never be welcome into a middle-class parlour, he needed his magazine to 
become a fixture there. So as he built the National Geographic Society into the organisation we still recognise today, he cultivated dignity and respectability and projected that image not just to the membership but also to the wider world. And when about 1915, tired of chasing down articles and pictures from a shifting and sometimes unreliable cast of diplomats, military men, wealthy travellers and gadabout rogues, he decided to build his own staff, he demanded of them gentlemanly behaviour above all. Those staff men who worked abroad were the 'foreign service' of the society, representing its interests and spreading its good name around the globe.

Thus was made that National Geographic 'manner'. By the 1930s, it was embodied in stone and marble in another 'manor': the society's Washington, DC, headquarters. Located only six blocks from the White House, it had Italian Renaissance detailing, panelled offices, and segregated dining rooms - the women in one, the men in the other-because it was feared the men might tell off-colour jokes in the presence of the ladies. Those ladies had to wear white gloves, and those gentlemen could not walk down the hall without donning their jackets. Ties, needless to say, were obligatory.

Yet it was a fitting headquarters for an institution that could now pride itself on having achieved a venerable status. With more than one million members, the National Geographic Society billed itself as the 'largest scientific and educational organization in the world'. Its magazine was found in every school and doctor's office in the United States. Always referred to with a capital ' $\mathrm{M}^{\prime}$ within those hallowed halls, the magazine, too, enshrined that sense of dignity on the one hand and exotic adventure on the other. Both were hinted at in the classic oakleaf cover that identified it from 1910 to the end of the 1950s. The border of oak leaves and acorns, it was said, represented the origins and sturdy growth of the society; the garland of laurel at the top was the traditional crown of achievement in the arts. The hemispheres - northern, southern, eastern and western - at the cardinal points suggested that the contents were indeed constrained only by 'the world and all that was in it'.

So established in the hearts of its members was this design that when in 1959 photographs first erupted onto the cover, an Englishman was reported to have written: 'If God had intended a picture on the cover of the National Geographic, he would have put one there in the first place. ${ }^{\prime}$

5 Jenkins, M. C. 1999, 'Birth of a classic: the 1910 oak-and-laurel cover', National Geographic TimeLine, National Geographic Archives, Washington, DC.

6 Jenkins, M. C. 2003, '1959: pictures erupt onto the cover', National Geographic TimeLine, National Geographic Archives, Washington, DC. 
This, then, was the National Geographic that Howell Walker grew up with.

Born Harrison Howell Dodge Walker on 4 August 1910, he came from an old and established Georgia family on his father's side and a New York one on his mother's. He was educated at St Alban's School in Washington, DC, and the Berkshire School in Sheffield, Massachusetts, before enrolling at Princeton University, where he was a track star as well as a 1933 graduate in languages.?

While other members of his class went on to become captains of industry and leaders of finance, Walker opted instead to be a walkabout magazine correspondent - a professional globetrotter. Of course, he did not just stroll in and get the job. He was told when he first stepped into the Geographic's marble foyer to go away, he had no experience.

So, he went away and got some, spending the better part of the next three years travelling around the world. And as he wandered he wrote, occasionally sending material back to National Geographic. The editors apparently liked what they saw. They conferred with the chief of the photo lab, who declared that the young man might be made into a passable professional photographer. Persistence paid off. On 2 March 1936, Howell Walker, aged twenty-five, was hired on a threemonth trial basis in the photo lab, the place where all aspiring young writer/ photographers started - wearing a smock with his name embroidered over the left-hand pocket, mixing chemicals in earthenware crocks.

He quickly proved himself in the field, though, and soon joined that elite corps of National Geographic 'triple threats', as they were called: those foreign editorial staff men - and they were all men at this time - who could take the pictures, write the story, and make the $16 \mathrm{~mm}$ travelogue film for the society's popular lecture series. Walker might have made a career producing such late 1930s period pieces as his early 'Adirondack idyls' and 'Gentle folk settle stern Saguenay' (alliteration being much favoured at the time), were it not for World War II. In early 1941, he was sent to cover the war effort in Australia; it was the luck of the draw as it might just as easily have been Greenland, where one of his colleagues was posted. The next five years proved to be the most pivotal of his life.

Initially, Walker was the well-behaved correspondent, writing articles such as 'The making of an Anzac' and 'Life in dauntless Darwin' for the magazine. Soon, he grew restless, and began peppering his dispatches with the phrase 'big yellow full moon' so as to goad the censors; they would always delete it, despite

7 Clippings: 'Walker, Howell', Library News Collection, National Geographic Society Library; and Z News Service Biographies: Walker, Howell, 38-1.153, National Geographic Archives. 
the fact that the same big yellow full moon shone on the Japanese as it did on the Allies. ${ }^{8}$ Finally, after a month's tour with US Army Air Forces, he joined up. In April 1943, in Brisbane, he was commissioned a second lieutenant, serving thereafter as an intelligence officer with the Fifth US Air Force from Australia to New Guinea and the Philippines, eventually rising to the rank of captain.

The war was not his only Australian complication. Sheila Gordon Anderson was the daughter of a prominent Sydney businessman and retired brigadier general. Howell met her in 1942, and before the year was out they were married. After the war he brought his bride to Washington and resumed his life as a National Geographic roving correspondent. Only now he had a beat. Whereas the magazine already had its 'Latin America man' and 'Middle East man', Howell now became its 'Australia man'. And it was not long before he returned Down Under.

The war had not yet ended when Charles Mountford toured the United States, lecturing and showing his films on Aboriginal life. Grosvenor and his editors found the films enchanting and thought that the Australian himself made an engaging figure. With unerring instinct, they realised their broad membership would also find his work appealing, and the upshot was that they invited Mountford to apply for a National Geographic Society research grant. Expeditions might have many beginnings, but that was certainly an important one for what became the Arnhem Land Expedition. Furthermore, the Secretary of the Smithsonian Institution, Alexander Wetmore, who happened to be a corresponding member of the Royal Australasian Ornithologists Union, was also a long-serving member of the National Geographic Society's board of trustees and a pillar of its Research Committee. That cosy relationship helped ensure joint backing of the proposed expedition. The Smithsonian would get its share of the collections, while the National Geographic would get the pictures. That meant sending Howell Walker back to Australia.

Of the tonnes of equipment the American Expedition members brought, Walker's share - except for the better part of $8 \mathrm{~km}$ of colour film-was low for the most part. Cases of still film and a battery of cameras - including largeformat Linhofs and Graflexes, medium-format Rolleiflexes, and the $35 \mathrm{~mm}$ Leicas that the magazine used almost exclusively for colour - were the common kit of the era. ${ }^{9}$ Peter Bassett-Smith, Mountford's filmmaker, used the popular Bolex, but Walker sported the big Kodak Ciné-Special movie camera. Last but not least, of course, he brought a portable typewriter.

8 Z News Service Biographies: Walker, Howell, 38-1.153, National Geographic Archives.

9 Jenkins, M. C. 2008, 'Luis Marden', in Odysseys and Photographs: Four National Geographic field men, National Geographic Society, Washington, DC, pp. 78-83. For details about various editorial demands and constraints on field photographers, I am indebted to personal conversations with the late Luis Marden. 
With his typewriter, Walker filed dispatches back to the office whenever he could. But news of Expedition mishaps - not all of it accurate-filtered out even when he could not. 'Five D.C. scientists reported marooned on primitive isle' ran the headline of the 21 April 1948 Washington Post, when the rains and floods on Groote Eylandt were at their worst. ${ }^{10}$ The only problem was, three of those five-David Johnson, Herbert Deignan and Howell Walker-were nowhere near Groote Eylandt; they were instead marooned on the 200-tonne supply ship, the Phoenix, stranded on a reef.

Eventually, they were rescued, of course, and, a few months later, after the Expedition had moved on to Darwin, Walker remained behind on Groote Eylandt to catch up on photography. In August, he clambered aboard the ketch Wanderer II, owned by the superintendent of Umbakumba Aboriginal Settlement, Fred Gray - and promptly went missing again. A search and rescue mission by the Royal Australian Air Force finally located Wanderer II holed up in an obscure harbour due to rough seas. That also landed on the front page of the Washington papers. 'I feel genuinely sorry and not a little sheepish about the reported-missing incidents', Walker wrote back to headquarters. ${ }^{11}$ But in those marble halls, unknown to him, he was already being dubbed the 'intrepidest explorer' because he had been twice listed as missing. No other Geographic man, it seems, had gone missing more than once. ${ }^{12}$

Wherever and whenever he did manage to catch up with the Expedition, Walker of course had plenty of work to do. Editors had 'shot lists' the photographers were supposed to follow. Though the bulk of the photography was in black and white, there were 'establishing shots', for instance, which needed to be saturated with what was called 'scenic colour'. A number of pictures were taken of the camp at Oenpelli (now Gunbalanya), for instance. Clearly, a morning was given over to posing for photographs. Move a few crates around, repose the people, make the cook wear his get-up, and switch over the Australian and American flags for a National Geographic Society flag that dwarfs them both combined - and you have the version the magazine published. Grosvenor never missed a chance to get that flag into the magazine - the brown stripe symbolised land, the green one sea, and the blue one sky, meaning the 'world and all that is in it' - because it served to remind the members that here was their society hard at work.

Such colour pictures were often posed not so much because imaginations were stilted as because early Kodachrome was slow: it had an ASA rating of eight (modern films and digital cameras are often at least ten times as fast). Although

10 Z News Service Expeditions: Australia Northern Territory Arnhem Land, 38-2.

11 Ibid.

12 Hunter, 'Howell Walker'. 
Walker could and did take hand-held action shots, the slow film often meant he put the $35 \mathrm{~mm}$ Leicas on tripods in order to ensure the sharp exposures necessary for proper colour engraving - always a tricky business at this time. That in turn necessitated set-ups or at least a pause in the action.

The dependence on Kodachrome imposed another constraint - this one more stylistic than technical. The National Geographic's editors also wanted landscape shots - sometimes derided as 'postcard views' - but the age of mass travel had yet to dawn and most Americans wanted to see what faraway places looked like. Grosvenor and the editors, however, demanded that people appear in the scene to give scale to geography. They even called it 'humanised geography'. Those people were usually garbed in red-red shirts, red scarves, red sweatersbecause when Kodachrome was first released in the mid-1930s, it was believed that the inclusion of some red in a picture helped make colours 'pop'. That, unfortunately, might have been taken to extremes at the Geographic, where photographers were instructed to carry red scarves and sweaters in their kit, giving rise to what later was sneeringly called the 'red-shirt school of photography'. Thankfully, Walker must have left those red scarves and sweaters behind, for they would have been decidedly out of place in 'Stone Age' Arnhem Land.

It was said that the 'Geographic man' always travelled first class, stayed in the finest hotels, and, because he was expected to be a gentleman, always carried a black tie. ${ }^{13}$ No doubt Walker had a twinkle in his eye when he set up the shot eventually printed on page 777 of 'Exploring Stone Age Arnhem Land', the major article on the Expedition, published in December 1949. There, for American eyes, was the Geographic gentleman in distant Australia, under the lee of Injalak Hill near Oenpelli. 'A Robinson Crusoe in Arnhem Land', states the caption. And the image does have an idyllically self-reliant quality. There is Walker, shirtless, at work in his improvised alfresco office; there is his rustic bed, his rolled-up mosquito net, his satchel, his portable typewriter, his riggedup lamp. There is even some rock art to gaze at on the ledge above him. In this outdoor bedroom, with the rains long past, Walker could fall asleep each night with the Southern Cross etched on his fluttering eyelids.

To his colleagues back at headquarters, however, it was an image that evoked freedom - not only freedom from the strictures of society, but from those of one society in particular. At the clean-cut National Geographic, where all the ladies wore white gloves and even moustaches were frowned upon, here was its Cary Grant: Howell Walker, with a beard.

13 Jenkins, 'Luis Marden', pp. 78-83. 
Of course he was out on expedition. But it is hard to imagine today, when beards are commonplace, how much attention they once attracted. The caption writers of the day could never resist pointing out, tiresomely, the deficiencies of barbering in faraway places. The picture was even used in an advertising appeal a year or so later. Under the title 'Have Typewriter, Have Traveled', the circular stated that eight months in Arnhem Land 'can't help but bring out a flair for improvisation in anybody'.14

Even today, for those few people at the National Geographic Society who still recognise the name Howell Walker, it is this image that comes to mind.

In subsequent years, Walker often returned to Australia. In 1954, he journeyed to Melville Island with Mountford in a kind of sequel to the Arnhem Land Expedition. Before his retirement in 1975, he wrote at least five more National Geographic stories on various Australian topics. By then, of course, times had changed at the society. Old Dr Gilbert H. Grosvenor had retired in 1954, after an impressive half-century at the helm. He was eventually succeeded, in 1957, by his son, the energetic Melville Bell Grosvenor, who promptly propelled the staid National Geographic Society in a multitude of exciting new directions. Throughout the golden years of the 1960s and 1970s - the era of Louis Leakey and Jane Goodall and Jacques Cousteau - the society's books and atlases and globes, and above all television documentaries, increasingly supplemented the National Geographic magazine in the public eye. Furthermore, an age of specialisation had set in. Gone were the days when the magazine depended on a foreign editorial staff composed of adroit 'triple threat' men who could do a little of everything in the field and do it reasonably well. Writers now became full-time writers and a corps of young Nikon-toting photojournalists - benefiting from faster films and eschewing posed set-ups, and including talented women-displaced the Leica-loving gentlemen of the previous generation. Howell Walker-his hair gone silver - ended his Geographic days in a cosy and decidedly conventional office, where behind his typewriter he mostly edited other people's manuscripts. Nevertheless, in a poll among the secretaries, he was still voted 'the man with whom they would most like to be stranded on a desert island'.15

He must have left them disappointed, because after he did retire, he and Sheila settled permanently in Australia, spending the last two decades of their lives together in an art-filled home in Woollahra, Sydney. Old friends who visited returned with the report that, before he died at the age of ninety-two on 26 January 2003, Howell Walker, once the epitome of the Geographic gentleman, was sporting a bushy white beard.

14 Z News Service Expeditions.

15 Hunter, 'Howell Walker'. 


\section{Acknowledgments}

The author wishes to thank his former colleagues Renee Braden, manager of the National Geographic's Archives and Special Collections, and Cathy Hunter, chief archivist, for help and assistance. 